УДК 316.323.65

\title{
ОСОБЕННОСТИ СОЦИАЛЬНОГО СТАТУСА И ЦЕННОСТНЫХ ОРИЕНТАЦИЙ МОЛОДОЙ СЕМЬИ РЕСПУБЛИКИ КРЫМ (СОЦИОКУЛЬТУРНОЕ ИССЛЕДОВАНИЕ)
}

\begin{abstract}
Марченко Святослав Витальевич студент

Научный руководитель: Лыкова Наталия Николаевна кандидат культурологии, доцент кафедры гуманитарных и социально-экономических дисциплин Крымский филиал ФГБОУВО «Российский государственный университет правосудия»
\end{abstract}

Аннотация: Объектом исследования настоящей статьи является молодая семья. В статье проанализирован социальный статус молодой семьи, как в Российской Федерации, так и в Республике Крым. В работе автор рассказывает о социальной поддержке молодых семей и даёт анализ демографической ситуации на полуострове. Помимо этого, автор использует статистические данные по числу зарегистрированных браков по городским округам и муниципальным районам Республики Крым в органах ЗАГС за 2021 год. В конце автор подводит общие итоги социального положения современных молодых семей в обществе, а также их значимость для общества и государства.

Ключевые слова: молодая семья, родственные отношения, национальные проекты, трансформации института семьи, молодежная политика, национальные традиции, культурные ценности. 


\title{
FEATURES OF THE SOCIAL STATUS AND VALUE ORIENTATIONS OF A YOUNG FAMILY OF THE REPUBLIC OF CRIMEA (SOCIO-CULTURAL RESEARCH)
}

\author{
Svyatoslav Vitalievich Marchenko \\ student \\ Scientific supervisor: Lykova Nataliya Nikolayevna \\ candidate of culturological sciences, docent \\ The Crimean branch of the Federal state budget \\ educational institution of higher professional education \\ "Russian state University of justice"
}

\begin{abstract}
The object of research of this article is a young family. The article analyzes the social status of a young family both in the Russian Federation and in the Republic of Crimea. In the work, the author talks about social support for young families and gives an analysis of the demographic situation on the peninsula. In addition, the author uses statistical data on the number of registered marriages in urban districts and municipal districts of the Republic of Crimea in the Registry Office for 2019. In the end, the author summarizes the general results on the social status of modern young families in society, as well as their significance for society and the state.

Key words: young family, family relations, national projects, transformations of the family institute, youth policy, national traditions, cultural values.
\end{abstract}

Основной материал: «Семья - ячейка общества». Эта всем известная фраза в подлиннике звучит несколько иначе. Фридрих Энгельс писал: «Семья - это экономическая ячейка общества». Всего одно слово, а разница довольно существенная. В современном обществе выделяется огромное количество классификаций и типологий семей, например:

- по наличию обоих родителей ( полная; неполная)

- по семейному стажу (молодожены; молодая семья; семья, ждущая ребенка; семья среднего супружества; старшего супружеского возраста; пожилая супружеская пара)

- по географическому признаку (городская, сельская, отдаленная)

и так далее 
Именно молодая семья, по мнению автора, играет одну из ключевых ролей. Ведь это зарождающая ячейка общества, благодаря которой будет дальнейшее развитее общества. Своим союзом, молодые семьи, зачастую укрепляют и улучшают демографическую ситуацию, как в Российской Федерации, так и в её субъектах [2] .

С семьи начинается жизнь человека, здесь происходит формирование его как гражданина. Именно родственные отношения являются источником сохранения национальных традиций и культурных ценностей.

Создать семью в России можно с 18 лет. Но нередко у новобрачных возникают проблемы - нехватка денег, образования, отсутствие собственного жилья. Государство старается поддерживать вновь созданные ячейки общества. Однако стоит обратить внимание, что хоть и государство предоставляет таким семьям дополнительные льготы и гарантии, но, чтобы на них претендовать, нужно быть благополучной ячейкой общества [2].

В юриспруденции, в настоящее время нет единого мнения по поводу определения термина «молодая семья». Так, согласно Основным направлениям государственной молодежной политики в Российской Федерации, к категории молодых семей отнесены семьи в первые три года после брака (в случае рождения детей - без ограничения продолжительности брака), при условии, что один из супругов не достиг 30-летнего возраста. А также неполные семьи с детьми, в которых мать или отец не достигли 30-летнего возраста [1].

Семейные отношения в России регулируются Семейным Кодексом и иными законодательными актами. Точное определение даётся в законах федерального и регионального уровня [3].

Семья как первичная ячейка общества непосредственно связана со всей общественной системой. Общество создает определенные условия для функционирования семьи, задает оптимальный уровень и качество ее жизни. В свою очередь семья воздействует на социальную организацию общества, определяет возможности и перспективы его развития.

Изучение молодой семьи, ее социального статуса и специфических проблем может дать ключ к пониманию процессов трансформации института семьи в целом, ее места в современном российском обществе. Именно этим и обусловлена актуальность темы исследования.

Сегодня проблемы российской семьи выходят на поверхность, становятся заметными не только специалистам. Это падение рождаемости, 
рост смертности, уменьшение брачности и рост разводимости, увеличение частоты добрачных и половых связей, увеличение частоты ранних и сверхранних, а также внебрачных рождений. Это и беспрецедентный рост числа отказов от детей и даже их убийств, и галопирующая подростковая и детская преступность, нарастание эмоционального отчуждения между членами семьи.

Молодые семьи эволюционируют, постоянно переходя от одного этапа жизнедеятельности к другому [2]. Это неизбежно связано с возникновением новых проблем. Проблемы современной молодой семьи касаются основных сфер жизнедеятельности: рождения и воспитания детей, обеспеченности жильем, трудоустройства и поиска рабочего места, взаимоотношений в семье, совместного досуга.

Семейный досуг играет большую роль в воспитании, как отдельной личности, так и семьи в целом. Социальная роль досуга заключена в том, что он служит неким средством восстановления физических и духовных сил человека, подготавливает его к дальнейшей трудовой и общественной деятельности, а также служит объединению семьи. Безусловно, повышению роли активного семейного досуга способствует благоприятный семейный климат, который состоит из двух «ингредиентов»: заботе и уважении. Поддержание здорового образа жизни, правильный ритм и режим жизни семьи, разумное распределение обязанностей между её членами, совместный труд и отдых - именно благодаря этим факторам формируется благоприятный семейный климат [3]. В свою очередь внутрисемейный климат оказывает сильнейшее влияние на все стороны жизни каждого члена семьи. Если отношениям внутри семьи характерны доверительность, моральная защита, сопереживание печалям и радостям, то такая семья способствует восстановлению и пополнению духовных сил её членов.

Сейчас заметна тенденция и к изменению отношений к семье и внутри семьи. Вследствие этого, постепенно формируется ценностное отношение к семье как к центру воспитания культуры и культурного досуга семьи [3].

Для оптимального решения задач социально-культурной работы по формированию культуры досуга молодой семьи, наиболее действенными на сегодняшний момент являются «культуротворческие» и «социальные технологии». Они реализовываются в культурно - массовых программах, достаточно разнообразны по формам. Наиболее распространенные и доступные формы: беседы, встречи, психологические тренинги, совместные 
занятия детей и родителей, семейные конкурсы, фестивали, спортивные программы.

Выделяются программы, связанные с освоением и педагогическим использованием определенной культурной среды, включая исторические и историко-культурные памятники, мемориальные комплексы, экологические зоны, художественные экспозиции, музейные занятия, и другие информационные, развлекательные, развивающие программы для семейных групп, в том числе программы выходного дня для населения [3]. Корпоративные программы предприятий все чаще модернизируются из чисто коллективных мероприятий в семейный досуг.

Примеров таких программ по всей территории России можно привести огромное количество. Ежедневно специалисты-профессионалы проводят спортивно-оздоровительные, культурно-развлекательные, тематические мероприятия, спартакиады, турниры [3]. Имеют место быть и тематические дискотеки «Дискотека 90-х»

В настоящее время заметно поднялись в приоритете духовные ценности, ценности культуры и искусства. Материальным ценностям отводится дальний план, в центре общественных интересов стоит человек, его внутреннее развитие. Сегодня формируется возврат к духовности человека. Люди все чаще обращаются к религии, верованиям в поисках ответов на вопросы о своем происхождении, а самое главное предназначении. Начинает культивироваться духовное начало в человеке, а значит, семья уже иначе пытается строить свое досуговое общения в семье, опираясь на нравственные взгляды, позиции, принципы членов семьи.

В современном Крыму, как и в России в целом «молодая семья» находится под особым вниманием Правительства. Существуют разнообразные виды социальной поддержки молодых семей, которые финансируются как из федеральных, так и из региональных бюджетов, например:

1. Ежемесячная денежная выплата при рождении (усыновлении) первого ребенка

2. Ежемесячная денежная выплата в связи с рождением третьего и последующих детей [1].

Рассматривая тему семей, страдающих бесплодием, стоит сказать, что проводятся циклы экстракорпорального оплодотворения.

На территории Республики Крым также реализуются программа по 
обеспечению жильем молодых семей. Мероприятие по обеспечению жильем молодых семей ведомственной целевой программы «Оказание государственной поддержки гражданам в обеспечении жильем и оплате жилищно-коммунальных услуг» государственной программы Российской Федерации «Обеспечение доступным и комфортным жильем и коммунальными услугами граждан Российской Федерации», утвержденной постановлением Правительства Российской Федерации от 30.12.2017 № 1710. Суть программы в том, что государство вносит за семью часть стоимости квартиры. Это не кредит, не льготная ипотека, а субсидия - деньги возвращать не придется. В программе могут участвовать молодые семьи. (Возраст каждого из супругов не больше 35 лет.) [4].

Рассматривая социальный статус семьи, также стоит, и упомянуть про национальные проекты. В современной России их огромное количество. С 2021 года Крым продолжает участие в 11 разнообразных национальных проектов - "Культура", "Образование", "Демография", "Жилье и городская среда", "Экология" и других. Все они реализуются в Крыму уже не первый год. Всех их связывает одна цель - повышение и улучшение жизни населения жителей нашей страны. Из огромного количества стоит выделить проект «Демография». Это национальный проект, касающийся практически всех граждан России. Поддержка семей с детьми, активного долголетия, занятости и здорового образа жизни - всё это относится именно к этому проекту. Данный проект имеет некие инициативы, федеральные проекты. Из пяти существующих, стоит выделить Федеральный проект «Помощь семьям при рождении детей». Одной из главных возможностью семей, в рамках данного Федерального проекта, является возможность получить материнский капитал [21]. С 2020 года материнский капитал получают семьи, в которых появился первый ребенок. Сумма маткапитала ежегодно индексируется в соответствии с уровнем инфляции. Материнский капитал можно, в частности, использовать для улучшения семейных жилищных условий. Помимо маткапитала, для семей предусмотрены ежемесячные выплаты на детей. Размер выплаты зависит от региона - он равен прожиточному минимуму для детей, который установлен в субъекте РФ. Пары, которые страдают бесплодием, могут бесплатно по полису ОМС воспользоваться технологиями экстракорпорального оплодотворения (ЭКО) [1].

Отдельное место, как в Крыму, так и в России в целом занимает многодетная семья. Многодетная семья - семья, в которой воспитываются 
трое и более детей в возрасте до 18 лет, включая усыновленных и принятых под опеку или попечительство. При обучении детей в организациях, осуществляющих образовательную деятельность в очной форме по основным общеобразовательным программам, профессиональным образовательным программами (или) по программам профессиональной подготовки по профессиям рабочих, должностям служащих за счет бюджетных ассигнований федерального бюджета. А так же бюджетов субъектов Российской Федерации или местных бюджетов - до окончания обучения, но не более чем до достижения ими возраста 23 лет.

Официальным документом, подтверждающим факт того, что та или иная семья является многодетной - является удостоверение многодетной семьи. Выдается Министерством образования, науки и молодежи Республики Крым.

Многодетные семьи имеют большое количество льгот. По закону Республики Крым от 17 декабря 2014 года № 39-3РК/2014 «О социальной поддержке многодетных семей в Республике Крым» это:

- Оплата в размере $50 \%$ занимаемой общей площади жилых помещений

- Оплата в размере 50 \% коммунальных услуг

- Внеочередное установление квартирных телефонов.

предоставляется льготный проезд в автобусах, троллейбусах, трамваях, следующих по маршрутам регулярных перевозок в городском и пригородном сообщении в пределах Республики Крым [1] .

А также пособий (по Федеральному закону от 19.05.1995 № 81-Ф3 "О государственных пособиях гражданам, имеющим детей"):

- Единовременное пособие при рождении ребенка.

- Ежемесячное пособие по уходу за ребенком

- Право на Государственную социальную помощь в виде социального пособия

- Ежемесячное пособие на ребенка.

- Ежемесячная денежная выплата на третьего или последующего ребенка [4].

Существование законов, направленных на материальную поддержку не только молодых, но и семей «со стажем» окажет положительное влияние на укрепление социального статуса молодой семьи, повысит её социальную значимость в обществе, что положительно скажется на повышении 408 
рождаемости и уровне благополучия значительной части молодых семей.

Говоря о статистике по Республике Крым. За 2019 год число зарегистрированных браков по городским округам и муниципальным районам Республики Крым, по данным регистрации органов ЗАГС составляет 13241 единица. Из них, наиболее высокое число из городских округов зарегистрировано в Симферополе, а именно 3020 единиц, а самое высокое число из муниципальных районов занял Симферопольский район с числом в 917 единиц [4].

В рамках реализации национального проекта «Демография» в Республике Крым с 14 августа 2020 года введена дополнительная мера социальной поддержки, направленная на улучшение жилищных условий семей, имеющих детей [1].

\section{Выводы и перспективы дальнейших исследований: Семья -} древнейший институт человеческого взаимодействия, уникальное явление. Ее уникальность состоит в том, что несколько человек самым тесным образом взаимодействуют в течение длительного времени, насчитывающего десятки лет, т.е. на протяжении большей части человеческой жизни.

Семья является важнейшим общественным институтом, имеющим решающее значение, как для индивидуальной жизни человека, так и для социального развития общества.

Существует тесная связь между формированием молодой семьи и другими социальными процессами - демографическими изменениями в обществе, его экономической и социальной стабильностью, а также его нравственным и физическим здоровьем.

Отмечаются изменения, трансформации в молодой семье, которые отражаются: в дестабилизации молодой семьи, так как растет число разводов и матерей-одиночек; в нарастании степени конфликтности во внутрисемейных отношениях, сочетающихся с неумением или нежеланием молодых людей улучшать некий климат семьи, разрешать возникающие конфликты компромиссом, взаимными уступками.

Однако в системе ценности молодых людей семья по-прежнему является одним из ведущих ценностных ориентиров. Более того, наблюдается тенденция к повышению её значимости у молодых супругов. Институт семьи в настоящее время имеет различное нормативно-правовое закрепление, которое в значительной степени обусловлено социокультурными традициями и социально- экономическими отношениями 
в обществе молодых супругов.

В настоящее время молодая семья, как никогда ранее, нуждается в социальной защищенности. Во взаимоотношениях молодой семьи государства важную роль различные социальные службы помощи молодой семье, которые как раз созданы для организации поддержки таких семей.

В настоящее время отношения государства и молодых семей в той или иной степени определены нормативно. Существуют различные программы, которые направлены на укрепление социального статуса молодой семьи. Они повысят её социальную значимость в обществе, что положительно скажется на повышении рождаемости и уровне благополучия значительной части молодых семей.

\section{Список литературы}

1. Статья заведующего отделом формирования, учета, хранения и выдачи документов Департамента записи актов гражданского состояния Министерства юстиции Республики Крым Олексюк С.Н. [Электронный pecypc]. - Режим доступа: https://must.rk.gov.ru/file/oleksuk.pdf

2. Ростовская Т.К Статус молодой семьи в современном российском обществе [Электронный ресурс]. - Режим доступа: https://cyberleninka.ru/ article/n/status-molodoy-semi-v-sovremennom-rossiyskom-obschestve/viewer

3. Реализация национального проекта «Демография» за сентябрь 2021 год [Электронный ресурс]. - Режим доступа: https://rpo.rk.gov.ru/ru/ document/show $/ 377$

4. Статистика от Управления Федеральной службы государственной статистики по РК и г. Севастополю по предоставлению данных органов ЗАГС «Число зарегистрированных браков и разводов по городским округам и муниципальным районам Республики Крым за 2019 год» [Электронный pecypc]. - Режим доступа: https://crimea.gks.ru/storage/mediabank

(C) С.В. Марченко, 2021 